Sanja Filipović
Neda Raspopović
Jelena Tošković
JEL: G17, G23, H63

DOI: 10.5937/industrija43-7709

UDC: $336.27(1-773)$

338.24.021.8

Original Scientific Paper

\title{
Correlation between reforms and foreign debt in transition countries ${ }^{4}$
}

\author{
Article history: \\ Received: 10 December 2014 \\ Sent for revision: 13 January 2015 \\ Received in revised form: 24 February 2015 \\ Accepted: 2 March 2015 \\ Available online: 1 April 2015
}

Abstract: After the global economic crisis escalated, transition countries indicated growth in their external debt. The aim of the paper is to determine the existence of a correlation between the transition reforms and the level of external debt. The research is based on applied Mann-Whitney $U$ Test on a sample of 27 transition countries. Transition countries are divided into two groups depending on whether their value of the average transition indicator in 2012 is greater or less than 3.4. The research has shown a positive and statistically significant correlation between the observed variables, i.e. that countries with higher average transition indicator have a greater external indebtedness. The regression analysis has found a positive and statistically significant correlation between the observed variables in the case of Serbia that enters the zone of high indebtedness. The research findings indicate the need to review the efficiency of existing economic policies as well as to define new direction of development that would provide the impetus to the economic growth of transition countries without additional external debt.

Keywords: transition economies, foreign debt, transition indicator

\footnotetext{
${ }^{1}$ Economics Institute, Belgrade, sanja.filipovic@ecinst.org.rs

2 University Edukons, Faculty of Business Economy, Novi Sad

${ }^{3}$ University Edukons, Faculty of Business Economy, Novi Sad

${ }^{4}$ This paper is a part of research project 179011 (Organizational and information support to the quality management system as a key factor in improving the competitiveness of domestic enterprises and ensuring their faster access to EU and world markets) and the project No. 47009 (European integrations and social and economic changes in Serbian economy on the way to the EU), financed by the Ministry of Science and Technological Development of the Republic of Serbia.
} 


\section{Veza između reformi i spoljnog duga u zemljama u tranziciji}

Apstrakt: Zemlje u tranziciji su u periodu nakon eskalacije globalne ekonomske krize zabeležile rast spoljne zaduženosti. Cilj rada je da se utvrdi da li postoji korelaciona veza između tranzicionih reformi i nivoa spoljnog duga. Istraživanje se bazira na primeni Mann-Whitney U testa na uzorku od 27 zemalja $u$ tranziciji. Zemlje $u$ tranziciji su podeljene $u$ dve grupe $u$ zavisnosti da li im je vrednost prosečnog tranzicionog indikatora u 2012. godini veća, odnosno manja od 3.4. Istraživanje je pokazalo da postoji pozitivna i statistički značajna veza između posmatranih varijabli, odnosno da zemlje koje imaju veći prosečni tranzicioni indikator imaju i veću spoljnu zaduženost. Primenom regresione analize utvrđena je pozitivna i statistički značajna veza između posmatranih varijabli i u slučaju Srbije koja ulazi u zonu visoke zaduženosti. Nalazi istraživanja ukazuju na potrebu preispitivanja efikasnosti postojećih ekonomskih politika kao i definisanja novog pravca razvoja koji bi bez dodatnog spoljnog zaduživanja dao zamajac privrednom rastu zemalja u tranziciji.

Ključne reči: zemlje u tranziciji, spoljni dug, tranzicioni indikator

\section{Introduction}

In the late 1980s, centrally planned economies (transition economies) began implementing economic and systemic reforms towards transformation into market economies. Building a market economy and rapid initiation of the transition program, which would open the process of market reforms, were supported by a political decision in the transition countries to abandon socialism and switch to capitalism. Such transformation allowed these countries to adopt new market rules implying privatization and deregulation of economic activities, liberalization of financial flows, gradual reduction of the government economic functions (Filipović, 2014), as well as the establishment of macro stability, economic restructuring and institutional reorganization (Gelb, Grey, 1991).

Although it took place under different scenarios in the transition countries, the process of economic reforms in all countries was based on ten recommendations defined in the economic program that was formalized by Washington Consensus (Williamson, 1990). This direction of economic reforms was strongly supported by advocates of neoliberal concept of the economy, mainly by the International Monetary Fund and the World Bank. The neo-liberal concept of economy implied reducing the government's impact and harsh fiscal austerity measures, as well as the free flow of capital, goods and services, which would lead to economic growth (Ljubojević, 2012). 
Significant market failures were evident after the first phase of transition, and they initiated the expanded set of recommendations for fighting corruption, the introduction of labour market flexibility, modified system of social protection, definition of poverty reduction measures, redefinition of financial standards, and similar (Williamson, 2004).

In the period after 2000, the institutional reforms were brought into focus, but the entire reform process slackened due to escalation of the global economic crisis. Until the moment of crisis outbreak, transition countries indicated significant economic growth rates and optimistic forecast of further economic development (Lissowska, 2014). According to the European Bank for Reconstruction and Development (EBRD), the average growth rate of Gross Domestic Product (GDP) in the transition countries in 2007 was $8.7 \%$, but plummeted to $-3.9 \%$ in 2009 after the start of recession. Empirical research conducted on a sample of 29 transition countries in the period 2008-2013, showed that countries with slower progress of reforms implementation felt less negative effects of the crisis in 2009, with regard to GDP growth rate (Filipović, Miljković, 2014). Furthermore, this subgroup of transition countries more successfully overcame the crisis during $2009-2013$, showing by $18 \%$ higher cumulative growth rate in a-five-year period than the transition countries that adopted all market economy principles.

The crisis weakened economic activity, stifled consumption and investment demand, and resulted in a slow decline in economic growth, loss of jobs and lower wages (WB, 2014a). The recession reduced the inflow of foreign capital, both bank loans and foreign direct investments (Bonta, 2012). Dampened aggregate demand and difficult access to capital had a negative bearing on the liquidity of the economy, and thus the growing debt of the economic sector after the economic crisis escalation. At the same time, a problem of budget deficit and its financing arose in most transition countries. Due to the lack of savings and foreign exchange, the needs for external sources have increased making the growth of external debt inevitable (Uzun and others, 2012). Seven years following the escalation of the global economic crisis, most transition countries emerged from the economic downturn, but in the meantime many of them concluded an arrangement with the International Monetary Fund for the evident problems of macroeconomic instability (Armenia, Belarus, Georgia, Kyrgyzstan, Moldova, Tajikistan, and Ukraine, Bosnia and Herzegovina, Serbia, Hungary, Latvia, Poland, and Romania), which further increased the level of external debt.

The aim of the paper is to investigate the existence of correlation between the progress of implemented economic system reforms and the level of external debt among two groups of transition countries grouped according to the average transition indicator of the EBRD. Special attention will be devoted to 
the analysis of the relation between the variables mentioned in the case of Serbia.

\section{Data}

The process of transition from centrally planned to market economy implied a dramatic economic, social and political changes. Most countries adopted the "shock therapy" model or strategy of rapid transition as a mechanism for quick gap bridging between the "under-developed socialist economies" and developed capitalist economies (Sachs, 1994). The "shock therapy" model was aimed at the implementation of the program of privatization and liberalization of foreign trade and financial flows. The consequences of this approach have been disastrous for economic growth so that a large number of transition countries faced the problem of transitional recession. In the period 1990-2000, the recession was most pronounced in Commonwealth of Independent States (CIS) $-3.8 \%$, followed by the countries of Central Europe and the Baltics (CEB) -2.5, and South-Eastern Europe (SEE) states $-0.96 \%$ (EBRD, 2000). Besides recession, a very big problem was the rise in unemployment and increase in social stratification and poverty (UN, 2011). A phase of transition recession in 2000 resulted in a sharp recovery of economic growth, amounting on average for all transition countries to $5.7 \%$. High rates of economic growth were retained by 2007, when the average economic growth rate was $8.7 \%$, while in the year of the global economic crisis escalation, the average economic growth rate decreased by $3.4 \%$ (EBRD, 2010). Transition countries emerged from recession in late 2010, when the average rate of GDP compared to 2009 was increased by $6.8 \%$. However, due to the crisis in Ukraine and tightening of monetary policies in developed countries, the fall was recorded again in 2013 , so that the average rate of economic growth for all transition countries was below $3 \%$.

Empirical research showed that countries that first emerged from the economic recession were the ones that opted for a gradualist approach to reforms, which implied building an institutional framework and support to new private sector development, which included: fully simplified procedure for establishment of new companies, tax incentives, financial sector support, improvement of the overall investment and business environment (Filipović, Andrejević, 2013). On the other hand, Havrylyshyn and Berg argued that countries that implemented ambitious programs of structural reforms were also the most successful in achieving macroeconomic stabilization (Havrylyshyn et al., 1999; Berg et al., 1999).

Measuring of progress in the implementation of transitional reforms is based on the methodology developed in 1994 by the EBRD. Methodology of 
Filipović S. et al.: Correlation between reforms and foreign debt in transition countries

transitional indicators includes quantitative evaluation of reforms performed by the given criteria. The scale of indicators ranges from 1 to $4+$, where 1 represents little or no change to the rigid centrally planned economy, while 4+ represents the standards of developed market economies. Designations "+" and "-" mark progress in relation to the previous year and indicate the rise and fall in the amount of 0.33 compared to the full value. In its annual Transition Report, the EBRD tracks progress in the implementation of economic reforms, and quantitatively assesses the progress based on six transition indicators, which relate to: privatization of large enterprises, privatization of small enterprises, enterprise restructuring, price liberalization, liberalization of foreign trade and competition policy.

In the early 2000s, there was a group of countries at the forefront of initiated market reforms that became members of the EU. The CEB countries successfully implemented economic reforms even during the 1990s, and thus 10 countries attained the status of EU member states in 2004, while Romania and Bulgaria became members in 2007. The SEE countries initiated the reforms earlier than the CIS countries and were more consistent in their implementation, which had bearing on the results, measured by transition indicator (De Melo, Denizer, Gelb, Tenev 1997). Figure 1 represents the average movement of the transition indicator in the transition countries.

Figure 1. Average transition indicator in transition countries 2000-2012

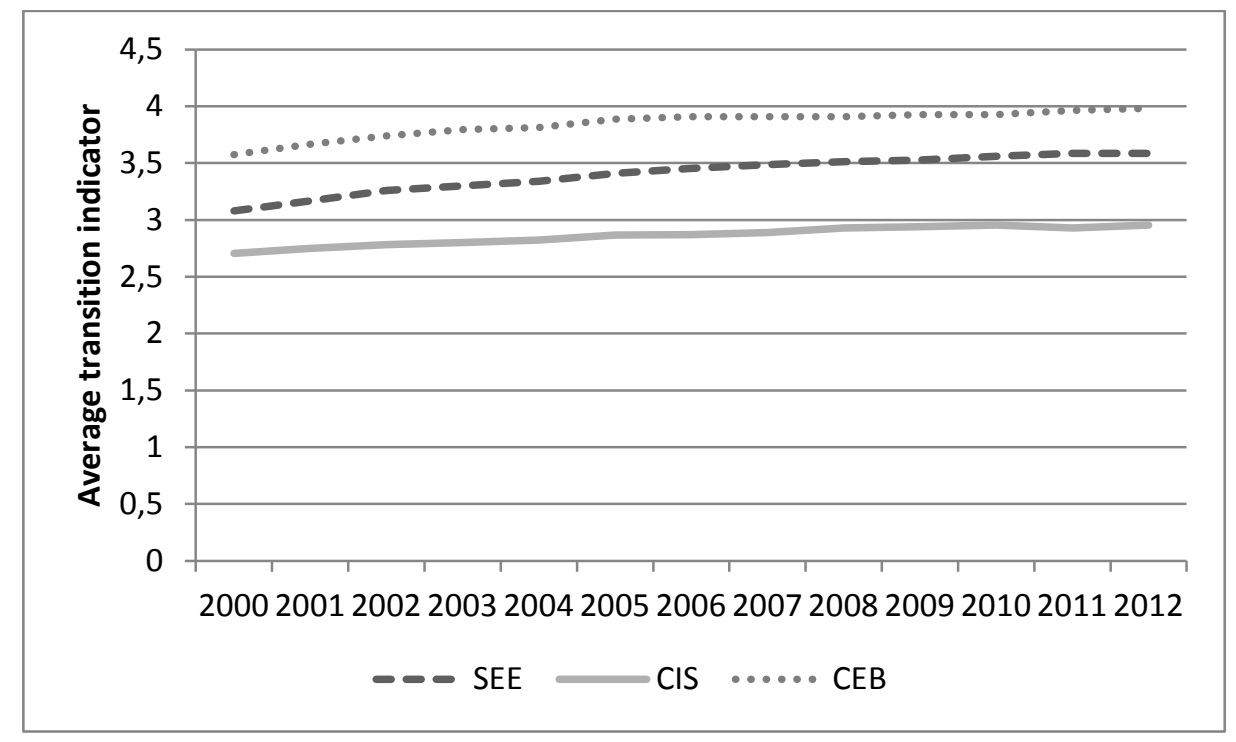

Source: the authors, based on EBRD data 
According to EBRD data, in 2000 total foreign debt of transition countries was $57.7 \%$ of GDP. The highest level of debt in 2000 was indicated by the SEE countries ( $62.3 \%$ of GDP), followed by CEB (58.4\% of GDP), and CIS (52.5\% of GDP). Unlike the CEB countries that until 2008 had downward trends in external debt, measured as \% of GDP, the countries of SEE and CIS had an increase in the indebtedness indicator since 2005. Total foreign debt of transition countries was $51.3 \%$ of GDP in 2008. Figure 2 represents the trend of foreign debt, measured as \% of GDP in transition countries in the period 2000-2012.

Figure 2. External debt as \% of GDP in transition countries 2000-2012

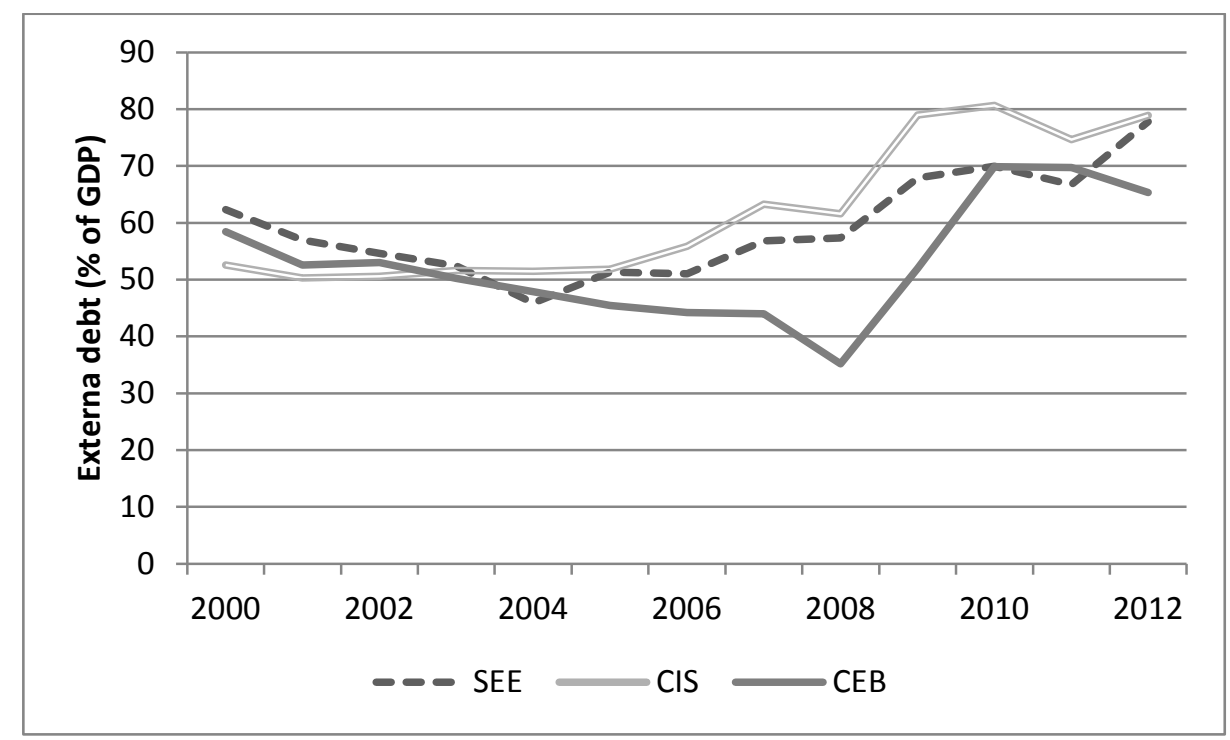

Source: the authors, based on EBRD data

In the year after the escalation of the global economic crisis, the largest amount of foreign debt was recorded in Latvia (161.9\% of GDP), Hungary (140.4\% of GDP), and Ukraine (88.2\% of GDP). Considering the average value, the CIS countries had the highest level of indebtedness $(80.6 \%$ of GDP), while the countries of SEE and CEB had almost uniform level of indebtedness (69.9\% of GDP). It is evident that the countries that had saved fiscal surplus and had a low level of external debt, and relatively high rates of savings and international reserves, were in a better position to finance the cost of the crisis of 2009 (UN, 2009). On the other hand, countries with a high level of external debt had more difficulties to mobilize resources to mitigate the effects of external shocks (Briguglio et al. 2008). In some countries (Armenia, Moldova, Poland and Turkey), the inflow of capital and renewal of 
remittances contributed to the growth and recovery in 2010 (EBRD, 2010). Figure 3 shows that countries with higher average transition indicator have a higher level of indebtedness measured by the share of external debt in GDP for 2012.

Figure 3. Average transition indicator and external debt as \% of GDP in transition countries in 2012

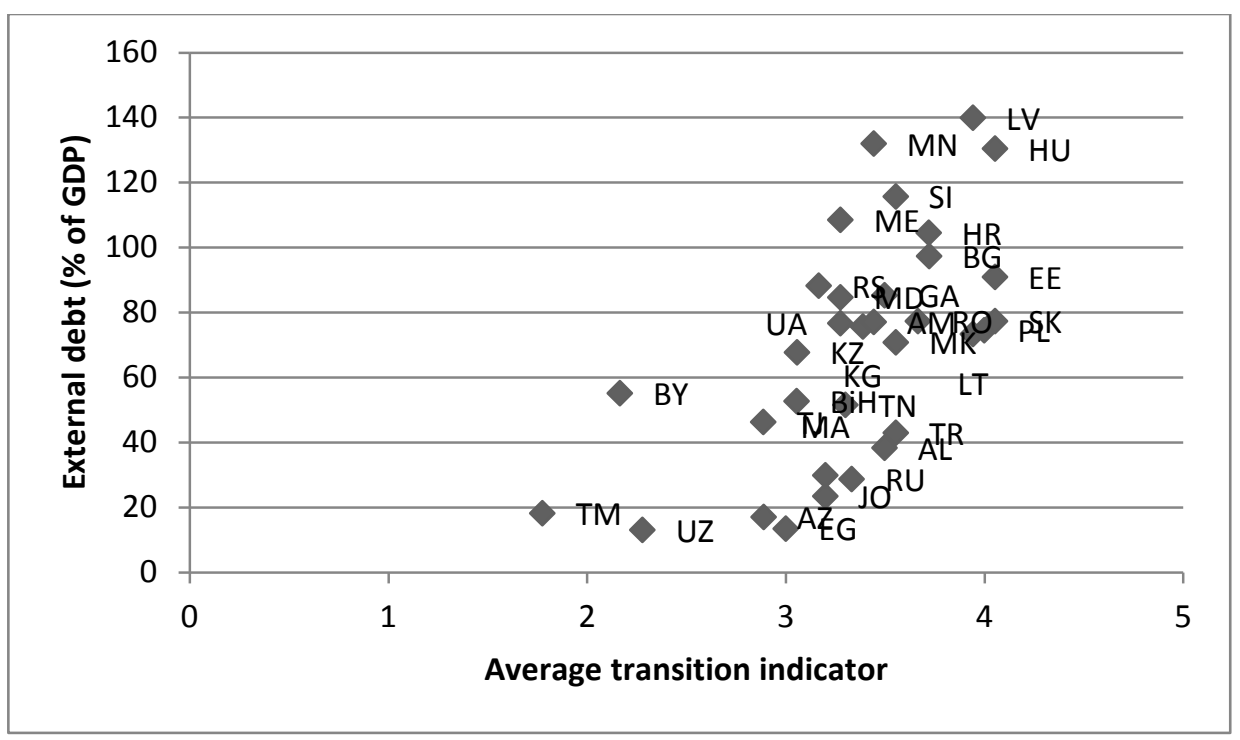

Source: the authors, based on EBRD data, Regional economic prospects, 2014

The transition process in Serbia started in the early 1990s, but almost a decade of reforms was lost due to the war in the region and NATO bombing. A new reform process was initiated in 2000 and the period that followed was marked by accelerated process of privatization and liberalization that facilitated the entry of foreign capital primarily in the area of banking, telecommunications and food industry companies. Progress in implementing the reforms was associated with the process of Serbia's EU accession. Average transition indicator and external debt in Serbia in the period 20002012 was presented by Figure 4.

Over the past thirteen years, the trend of foreign debt in Serbia was dynamic. In 2000, Serbia's external debt amounted to about EUR 10 billion, with the largest debt to the London and Paris Club in the amount of EUR 6.5 billion, while the debt to all remaining creditors amounted to EUR 3.5 billion (NBS, 2014b). After years of negotiations with the London and Paris Club, the largest part of the debt was written off and the rest was restructured. In the 
Filipović S. et al.: Correlation between reforms and foreign debt in transition countries

period 2000-2007, the upward trend of indebtedness was moderate, and the most important creditor was the International Bank for Reconstruction and Development, after which the borrowing process started from the European Investment Bank and the European Bank for Reconstruction and Development (NBS, 2014a). In the period 2008-2013, the level of debt increased towards international financial institutions, notably the IMF, where after the signing of the Arrangement of 2011 the debt rose to over EUR 2 billion. A new three-year Stand-By Arrangement from the IMF should be approved in February 2015.

Figure 4. Average transition indicator and external debt in Serbia 2000-2012

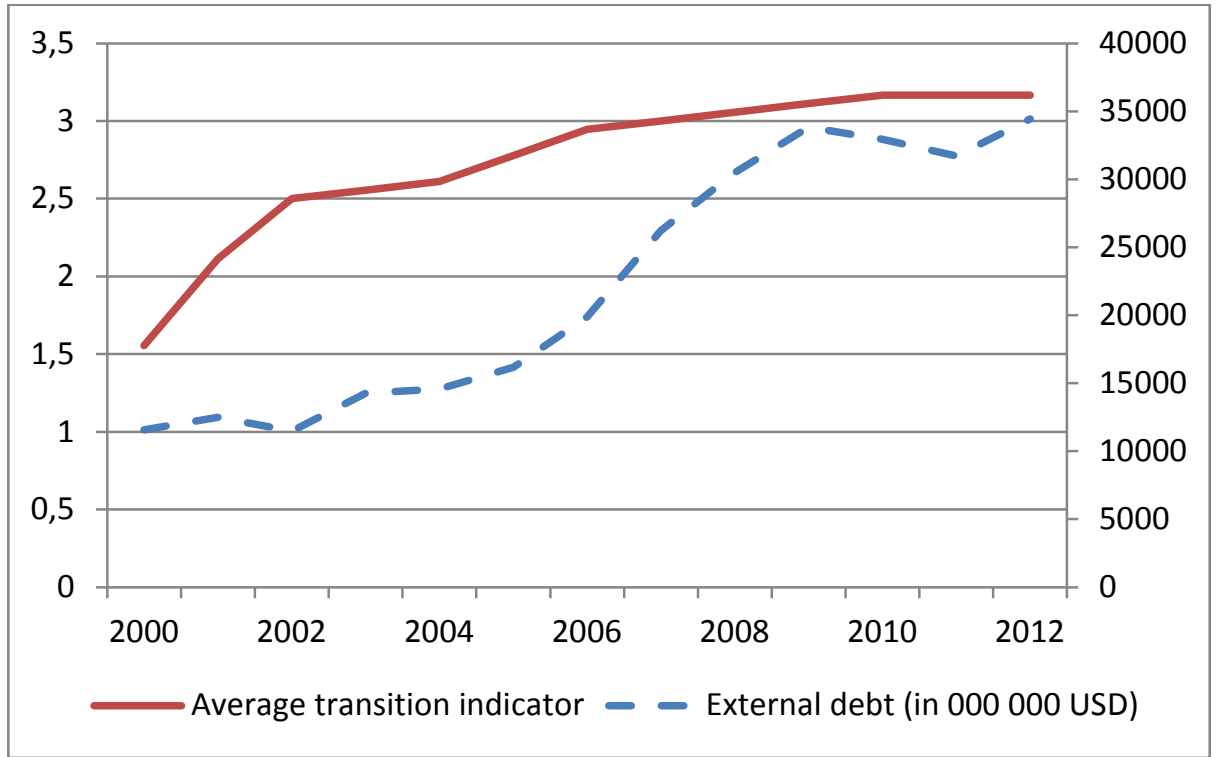

Source: the authors, based on WB data

Observing the external debt relative to GDP, the level of external debt in 2000 amounted to $164 \%$. By 2005 , external debt had a downward trend, and after short-term fluctuations in 2006, foreign debt had a continuous upward trend. According to the latest data of the National Bank of Serbia, external debt in the third quarter of 2014 amounted to $78.9 \%$ of GDP.

Serbia currently also insists on the injection of fresh capital to cover its budget deficit, which is only possible with adequate debt management policy, and which would allow the state to use external debt procedure without creating problems in the balance of payments (Adžić, Tošković, Marković, 2014). 
Filipović S. et al.: Correlation between reforms and foreign debt in transition countries

\section{Methodology of Research}

The aim of the paper is to determine whether there is a correlation between the progress in the implementation of economic reforms and the level of external debt. Progress in implementing the economic reforms will be measured by the average transition indicator under EBRD's methodology, while data on external debt are obtained from statistics of the EBRD available at www.ebrd.com.

The main purpose of this research is to first determine whether there is a statistically significant difference between two groups of transition countries, grouped by the values of the average transition indicator from 2012, in terms of the amount of external debt as a percentage of GDP. The initial idea was to determine whether the transitional countries that have higher average value of the transition indicator also record a higher percentage of foreign debt in relation to GDP. In the case of Serbia, it was analysed whether there is a statistically significant effect of the average transition indicator on the growth of external debt.

The first part of the research included 27 countries in transition by EBRD classification. For the purposes of Mann-Whitney $U$ test, transition countries are divided into two groups (Table 1), depending on whether their value of average transition indicator in 2012 is greater or less than 3.4. The MannWhitney $U$ test, also referred to as the Wilcoxon rank-sum test, analyses whether two independent samples are drawn from two populations that have the same relative frequency distribution. This test directly considers the rankings of the observations in each sample (Lee, 2013).

The Mann-Whitney $U$ test is used to analyse differences between two independent groups in terms of a continuous variable. The study covered the difference between the two aforementioned groups of countries depending on the value of external debt as \% of GDP. 
Filipović S. et al.: Correlation between reforms and foreign debt in transition countries

Table 1. Two groups of transition countries by average transition indicator and external debt as a percentage of GDP (2012)

\begin{tabular}{|c|c|c|c|}
\hline \multicolumn{3}{|c|}{ Average transition indicator $\leq 3.4$} & \multirow{2}{*}{$\begin{array}{c}\begin{array}{c}\text { External debt } \\
\text { (\% of GDP) }\end{array} \\
52.6\end{array}$} \\
\hline 1. & $\begin{array}{ll}\text { Bosnia } & \text { and } \\
\text { Herzegovina } & \\
\end{array}$ & 3.06 & \\
\hline 2. & Montenegro & 3.28 & 108.4 \\
\hline 3. & Serbia & 3.17 & 88.1 \\
\hline 4. & Azerbaijan & 2.89 & 17 \\
\hline 5. & Belarus & 2.17 & 55.1 \\
\hline 6. & Moldova & 3.28 & 84.6 \\
\hline 7. & Ukraine & 3.28 & 76.6 \\
\hline 8. & Russia & 3.33 & 28.6 \\
\hline 9. & Kazakhstan & 3.06 & 67.6 \\
\hline 10. & Kyrgyz Rep & 3.39 & 75.6 \\
\hline 11. & Tajikistan & 2.89 & 46.2 \\
\hline 12. & Turkmenistan & 1.78 & 18.1 \\
\hline 13. & Uzbekistan & 2.28 & 13 \\
\hline 14. & Egypt & 3 & 13.4 \\
\hline 15. & Jordan & 3.20 & 23.4 \\
\hline 16. & Morocco & 3.20 & 29.8 \\
\hline 17. & Tunisia & 3.30 & 51.4 \\
\hline \multicolumn{3}{|c|}{ Average transition indicator $>3.4$} & \\
\hline 1 , & Croatia & 3.72 & 104.5 \\
\hline 2. & Estonia & 4.06 & 90.8 \\
\hline 3. & Hungary & 4.06 & 130.3 \\
\hline 4. & Latvia & 3.94 & 139.8 \\
\hline 5. & Lithuania & 3.94 & 73.3 \\
\hline 6. & Poland & 4 & 74.4 \\
\hline 7. & Slovak Rep & 4.06 & 77.2 \\
\hline 8. & Slovenia & 3.56 & 115.6 \\
\hline 9. & Albania & 3.50 & 38.3 \\
\hline 10. & Bulgaria & 3.72 & 97.2 \\
\hline 11. & FYR Macedonia & 3.56 & 70.7 \\
\hline 12. & Romania & 3.67 & 77.3 \\
\hline 13. & Turkey & 3.56 & 42.8 \\
\hline 14. & Armenia & 3.44 & 77 \\
\hline 15. & Georgia & 3.50 & 85.2 \\
\hline 16. & Mongolia & 3.44 & 131.9 \\
\hline
\end{tabular}

Source: Author

Further analysis included the correlation between external debt and the average transition indicator in Serbia. Pearson's linear correlation coefficient 
was used as a measure of correlation between random variables (BiljanAugust, Pivac, Štambuk, 2007):

$$
r=\frac{\sum_{i=1}^{n} X i Y i-n \bar{X} \bar{Y}}{n \sigma_{x} \sigma_{y}}
$$
form of correlation between a dependent variable, i.e. regressand (external debt) and the independent variable, i.e. regressor (average transition indicator), which can serve as the basis for predicting values of the dependent variable at specific values of the independent variable. The regression equation is:

$y=a x+b$

where $\mathrm{x}$ is the independent variable and $\mathrm{y}$ depends on $\mathrm{x}$. A common statistical measure used to compute $a$ and $b$ is the least-squares criterion which minimizes the sum of squared differences between actual and predicted output values (Roiger, Geatz, 2003).

Null hypothesis of $F$ test is that coefficient of determination equals zero $\left(r^{2}=0\right)$, against alternative hypothesis $r^{2} \neq 0$. Null hypothesis of $t$-test is that $a=0$, i.e. variable does not provide statistically significant contribution to the equation, against the alternative hypothesis $a \neq 0$.

\section{Results and discussion}

The aim of the Mann-Whitney $U$ test in the present study was to investigate the differences between two groups of transition economies in terms of defined indicator (external debt as a percentage of GDP) in 2012. The results of this test are given in Table 2:

Table 2. Mann-Whitney $U$ test

\begin{tabular}{|l|l|l|l|}
\hline & Mann-Whitney & Z & $p$ \\
\hline $\begin{array}{l}\text { External debt (\% of } \\
\text { GDP) }\end{array}$ & 49 & -3.134 & 0.002 \\
\hline
\end{tabular}

Source: Author 
Filipović S. et al.: Correlation between reforms and foreign debt in transition countries

The value $Z$ in this tests is -3.134 , with a significance level of $p=0.002$. Since $p<0.05$, this result is significant, i.e. there is a statistically significant difference in the external debt as a percentage of GDP between these two groups.

In order to determine the group where the analyzed variable is bigger, Table 3 shows the median of each group. Countries that have higher average transition indicator record greater indebtedness, i.e. higher average value of external debt as a percentage of GDP. This confirmed that transitional countries that made more progress in the transition process, recorded a higher percentage of foreign debt in relation to GDP.

Table 3. Medians of analyzed groups

\begin{tabular}{|l|l|l|}
\hline & $\begin{array}{l}\text { Number of } \\
\text { countries }\end{array}$ & Median \\
\hline $\begin{array}{l}\text { Group 1 (Average transition } \\
\text { indicator } \leq 3.4)\end{array}$ & 17 & 51,40 \\
\hline $\begin{array}{l}\text { Group 2 (Average transition } \\
\text { indicator >3.4) }\end{array}$ & 16 & 81,25 \\
\hline
\end{tabular}

Source: Author

The goal of regression analysis in this study is to determine whether there is a correlation, and to what extent, between the average transition indicator and external debt in the case of Serbia. The data of these two variables for the period 2000-2012 are given in Table 4.

Table 4. External debt and average transition indicator of Serbia

\begin{tabular}{|l|l|lr|}
\hline year & $\begin{array}{l}\text { External debt (in 000 } \\
\text { USD) }\end{array}$ & $\begin{array}{l}\text { Average } \\
\text { indicator }\end{array}$ & transition \\
\hline 2000 & $11,573,165$ & & 1.56 \\
\hline 2001 & $12,478,684$ & 2.11 \\
\hline 2002 & $11,490,192$ & 2.50 \\
\hline 2003 & $14,259,748$ & 2.56 \\
\hline 2004 & $14,562,777$ & 2.61 \\
\hline 2005 & $16,159,381$ & 2.78 \\
\hline 2006 & $19,885,771$ & 2.95 \\
\hline 2007 & $26,211,640$ & 3 \\
\hline 2008 & $30,493,343$ & 3.06 \\
\hline 2009 & $33,813,839$ & 3.11 \\
\hline 2010 & $32,934,661$ & 3.17 \\
\hline 2011 & $31,724,198$ & 3.17 \\
\hline 2012 & $34,438,261$ & 3.17 \\
\hline
\end{tabular}

Source: Author 
Based on the scatter diagram (Figure 5) it can be concluded that there is a statistical correlation between the observed variables that is positive, so that growth of the dependent variable (external debt) follows the growth of the independent variable (average transition indicator), provided that the value of the average transition indicator for the last three years is constant. Positive and negative deviations from the main course are due to the influence of other random variables.

Figure 5. Dispersion diagram

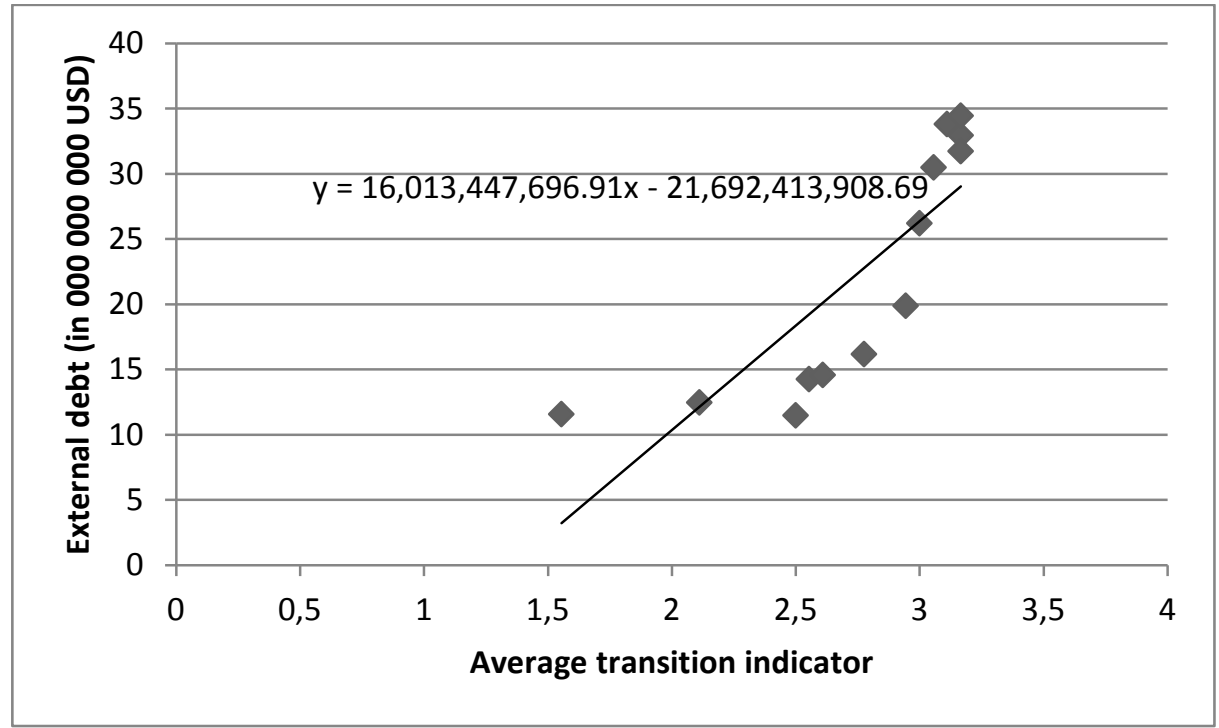

Source: Author

The results of regression analysis are indicated in Table 5. Correlation coefficient of 0.82 implies a good positive correlation between these variables. Determination coefficient $r^{2}$ is 0.678 in this case, which means that regression model explains $67.8 \%$ of variance of the dependent variable (external debt). Table 5 shows the results of $F$ test with degrees of freedom 1 and 11 , and $t-$ test with 11 degrees of freedom. $F$ test shows that Sig. $F<0.05$, which means that the model becomes statistically significant and the null hypothesis can be rejected at the significance level of $5 \%$. The null hypothesis of T-test, reading that independent variable does not have a statistically significant influence on the dependent variable, is rejected at the significance level of $5 \%$, with respect to the $P$-value $<0.05$. 
Filipović S. et al.: Correlation between reforms and foreign debt in transition countries

Table 5. Regression analysis results

\begin{tabular}{|c|c|c|c|c|c|c|}
\hline \multicolumn{4}{|l|}{$\bar{r}$} & \multicolumn{3}{|c|}{0.823125} \\
\hline \multicolumn{4}{|l|}{$r^{2}$} & \multicolumn{3}{|c|}{0.6775344} \\
\hline \multicolumn{4}{|c|}{ Observation } & \multicolumn{3}{|l|}{13} \\
\hline \multicolumn{7}{|l|}{ ANOVA } \\
\hline & df & \multicolumn{2}{|l|}{ MS } & \multicolumn{2}{|l|}{$F$} & Significance F \\
\hline $\begin{array}{l}\text { Regressio } \\
\mathrm{n} \\
\text { Residual } \\
\text { Total }\end{array}$ & $\begin{array}{l}1 \\
11 \\
12\end{array}$ & \multicolumn{2}{|c|}{$\begin{array}{l}71863992112306200 \\
0000 \\
34202921381224200 \\
0000\end{array}$} & \multicolumn{2}{|c|}{$\begin{array}{l}23.11217525 \\
616\end{array}$} & 0.000546716 \\
\hline & & Coefficients & \multicolumn{2}{|r|}{ t-Stat } & & P-value \\
\hline \multicolumn{2}{|l|}{ Intercept } & $\begin{array}{l}- \\
21692413908.6 \\
934\end{array}$ & \multicolumn{2}{|c|}{$\begin{array}{l}- \\
2.3369109729 \\
74\end{array}$} & \multicolumn{2}{|c|}{0.039386265} \\
\hline \multicolumn{2}{|l|}{$X$ variable } & $\begin{array}{l}16013447696.9 \\
07\end{array}$ & \multicolumn{2}{|c|}{$\begin{array}{l}4.8075123771 \\
193\end{array}$} & \multicolumn{2}{|c|}{0.000546716} \\
\hline
\end{tabular}

Source: Author

Regression equation is as follows:

$Y=16,013,447,696.907 X-21,692,413,908.6934$

Regression coefficient a shows that the external debt is increased by approximately USD 1.6 billion, when the average transition indicator is increased by 0.1 . Based on the results of regression analysis, a statistically significant influence of the average transition indicator on external debt is found in case of Serbia.

\section{Conclusion}

For two and a half decades, transition countries have been implementing the program of economic reforms that is based on the introduction of market conditions and building of institutions. Many of them have achieved remarkable progress measured by transition indicator and have since become members of the European Union. However, the global economic crisis has shown the vulnerability of their economies despite the reforms carried out. 
Empirical studies have shown that countries with bigger progress in the implementation of transitional reforms at the same time felt more negative effects of the crisis as measured by GDP growth rate. By implementing transitional reforms under the neo-liberal concept of economy, transition countries open their path towards liberalization, deregulation, and are thus more involved in international capital flows. The global economic crisis like a tide has brought to the surface many misconceptions and left behind the problem of a growing budget deficit and the economy hungry for investments. Even though the International Monetary Fund advocates savings, an increasing number of transition countries fall into growing foreign debt.

The study conducted on a sample of 27 transition countries shown a statistically significant difference in the external debt as a percentage of GDP between two groups of countries divided depending on whether the value of the average transition indicator is greater or less than 3.4. The results of Mann-Whitney $U$ test indicated that countries with higher average transition indicator have a higher level of indebtedness, i.e. on average greater value of external debt as a percentage of GDP.

While it seems that transition countries are caught in a vicious circle, a group of countries emerged like islands popularly known as the BRIC countries, which due to their specificities defined different direction of development. Brazil and Russia have achieved their progress thanks to cheap resources, while India and China used cheap labour as a lever of development. These countries have succeeded owing to their resources and well-defined development policy to remain almost immune from the impact of the global economic crisis. As these fast-growing economies are characterized by low ratio of external debt in relation to GDP, it is an additional argument for reconsideration of efficiency of development policies applied by transition countries. This is supported by latest developments related to the changed course of economic policy in Greece, but also mass protests in other countries that officially support the austerity policy and measures.

\section{Reference}

Adzic J. Toskovic J., Markovic J. (2014), Analysis of the external position of the Republic of Serbia; Structure and trend of foreign debt, Journal of Business Economics, Faculty of Business Assistance, Educons University, Sremska Kamenica, pp. 67-89.

Berg, Andrew and others (1999), The Evolution of Output in Transition Economies: Explaining the Differences, IMF Working Paper 99173, IMF, Washington, D.C.

Biljan-August, M., Pivac, S. Stambuk. (2007), The use of statistics in the economy, Faculty of Economics, University of Rijeka, Rijeka, Croatia. 
Filipović S. et al.: Correlation between reforms and foreign debt in transition countries

Bonta L.A. (2012), The Current Economic Crisis: Effects, Consequences, Measures and Solutions, Postmodern Openings, 2012, Volume 3, Issue 3, pp: 107-122, http://postmodernopenings.com

Briguglio L., Cordina G., Farrugia N. and Vella S. (2008), Economic Vulnerability and Resilience: Concepts and Measurements, Research Paper No. 2008/55, United Nations University-WIDER, Helsinki.

De Melo M, Denizer C, Gelb A, Tenev S (1997), Circumstances and Choise: The Role of Initial Conditions and Policies in Transition Economies, Washington, IFC.

Gelb A., Gray Ch. (1991), The Transformation of Economies in Central and Eastern Europe, World Bank Policy and Research Series No. 17, The World Bank, Washington.

Havrylyshyn Oleh, Ivialo Izvorski and Ron van Rooden (1998), Recovery and Growth in Transition Economies, 1990-97: A Stylized Regression Analysis, IMF Working Paper No. 98/141.

Filipović S. (2014), The great recession and crisis of neoliberal economy - Review of neoliberal concept in the Western Balkan countries, book 5, University of EDUCONS, Sremska Kamenica, pp. 125-142.

Filipovic S, Andrejevic A. (2013), The second episode of the economic crisis in the region, Third Scientific Meeting Educons University, The second wave of economic crisis-effects on the economy of the region and possible solutions, Sremska Kamenica, pp. 125-143.

Filipović S. \& Miljković M. (2014), Transition Economies during Global Economic Crisis: A Difference in Differences Approach, Industrija Journal of sustainable economics, Vol.42, No.3, pp. 23-41.

EBRD. Transition indicators by country. $\frac{\text { http://www.ebrd.com/pages/research/economics/data/macro.shtml\#ti\& }}{\text { Transition }}$

$\begin{array}{lcc}\text { EBRD, } & \text { Transition } & \text { report } \\ \text { http://www.ebrd.com/downloads/research/transition/TR00.pdf }\end{array}$

EBRD,
http://www.ebrd.com/downloads/research/transition/tr10.pdf

Lee C. F., Lee J. C., Lee A. C. (2013), Statistics for Business and Financial Economics, Springer.

Lissowska M. (2014), Welfare against Growth Gains in Post-Transition Countries. What are the Consequences for Stability? http://dx.doi.org/10.5018/economicsejournal.ja.2014-13

Ljubojevic M. (2012), The increase in poverty, transition and globalization, Fond Slobodan Jovanovic http://www.slobodanjovanovic.org/2012/10/05/ljubojevicporast-siromastva-tranzicija-i-globalizacija-iv/

$\begin{array}{lllll}\text { National } & \text { Bank } & \text { of } & \text { Serbia } & \text { (2014a), }\end{array}$ http://www.nbs.rs/internet/latinica/40/40 1/index.htm

National Bank of Serbia (2014b), Statistics - External debt, http://www.nbs.rs/internet/cirilica/90/dug/index.html

Sachs J. (1994), Shock Therapy in Poland: Perspectives of Five Years, Tanner lectures, University of Utah.

Roiger J.R., Geatz.W.M. (2003.), Data Mining, Addison-Wesley, USA

UN (2009), Economic resilience and fiscal capacity, http://www.undp.org/content/dam/undp/library/Poverty\%20Reduction/Inclusive $\% 2$ 
Filipović S. et al.: Correlation between reforms and foreign debt in transition countries

Odevelopment/Towards\%20Human\%20Resilience/Towards SustainingMDGProg ress Ch7.pdf

UN The global social crisis, http://www.un.org/esa/socdev/rwss/docs/2011/rwss2011.pdf

Uzun A., Karakoy C., Kabadayi B., Selcuk E. O. (2012), The Impacts of External Debt on Economic Growth in Transition Economies, Chinese Business Review, Vol. 11, No. 5, pp. 491-499.

World Bank (2014a), http://www.worldbank.org/financialcrisis/bankinitiatives.htm.

World Bank (2014b), External Debt Stocks, total (DOD, current US\$) http://data.worldbank.org/indicator/DT.DOD.DECT.CD/countries

Williamson, J. (1990), What Washington means by policy reform, Latin American Adjustment. How much has happened?, Washington, Institute for International Economics.

Williamson, J. (2004), A Short History of the Washington Consensus, CIDOB, Barcelona. 